\title{
Screening of Exotic Potato Germplasm against Potato Virus PVX, PVY and PLRV through Biological and Serological Test (ELISA)
}

\author{
Arifa Khan ${ }^{1 *}$, Danish Anwar ${ }^{2}$, Shazia Erum ${ }^{3}$, Naveeda Riaz ${ }^{1}$,Shahid Riaz ${ }^{4}$, Tariq Rafique ${ }^{3}$ and Zafer Iqbal $^{2}$
}

${ }^{1}$ International Islamic University, Islamabad, Pakistan; ${ }^{2}$ Hazara University Mansebra Pakistan; ${ }^{3}$ Bio Resources Conservation Institute, National Agriculture Research Center, Islamabad, Pakistan; ${ }^{4}$ Potato Program National Agriculture Research Center, Pakistan.

Abstract | Potato viruses like PVX (Potex virus X), PVY (Poty virus Y) and PLRV (genus Polerovirus, family Luteoviridae) cause significant yield loss of potato crop in the world including Pakistan. In this regard, 30 exotic potato genotypes were screened against the PVX, PVY and PLRV in field conditions during two seasons 2015-2016. Results showed that all the genotypes had resistance against PVX and PLRV however four genotypes (CIP-3, CIP-9, CIP-11 and CIP-14) were susceptible to PVY. Results regarding yield and tuber external quality showed that CIP-30 was taller genotype with medium number of tubers and shoots plant $^{-1}$ while CIP-5 was a dwarf genotype with minimum tuber yield. Genotype CIP-6 produced more number of tuber plant ${ }^{-1}$ but CIP-22 followed by CIP-10 produced the highest tuber yield plant ${ }^{-1}$. Majority of genotypes produced round shape tuber with yellow, white skin color and cream flesh. Likewise, maximum genotypes had medium to shallow eye tubers except CIP-9 and CIP-13, which had deep eyed potato tubers. In short, genotypes CIP-3, CIP-9, CIP-11 and CIP-14 showed susceptibility to PVY virus. Among resistant genotypes, CIP-10 and CIP-22 possessed greater yield and could be suggested for commercial cultivation in Pakistan.

Received | February 14, 2020; Accepted | August 21, 2020; Published | September 18, 2020

*Correspondence | Arifa Khan, International Islamic University, Islamabad, Pakistan; Email: arifa.phdbt55@iiu.edu.pk

Citation | Khan, A., D. Anwar, S. Erum, N. Riaz, S. Riaz, T. Rafique and Z. Iqbal. 2020. Screening of exotic potato germplasm against potato virus PVX, PVY and PLRV through biological and serological test (ELISA). Sarhad Journal of Agriculture, 36(3): 986-991.

DOI | http://dx.doi.org/10.17582/journal.sja/2020/36.3.986.991

Keywords | ELISA, Potato, Virus, PVX, PVY

\section{Introduction}

$\mathrm{M}$ ultidimensional factors determine the yield and total productivity of any crop. Generally, yield of potato depends on genetic makeup of genotype, ability of plant to produce tubers of suitable size, response of genotypes to environment (temperature, humidity and solar radiation, rain fall) and edaphic condition such as soil moisture and fertility. However, biotic factors such as virus and fungal diseases are very important that can decrease yield and productivity (Lutaladio et al., 2009). In Pakistan, occurrence of different diseases on potato crop caused by viruses has continually being documented. Among documented viral diseases, PVX, PVY and PLRV have depicted more in reports (Hameed et al., 2014). Potato virus $\mathrm{X}$ is a plant pathogenic virus and causes chlorosis between veins, rugosity, mild mosaic and sometimes severe necrosis occurs. Infected plant gives fewer tubers with less weight and size. These viruses can be latent viruses because they can continue latent in affected plants and hence sometimes unable to recognize on symptoms basis. Approximately, 20 viruses are detected that affect the potato plants but PVX, PVY and PLRV are more important that can cause great damage to potato crop and main cause 
of yield reduction in Pakistan. However, Hameed et al. (2014) and Abbas et al. (2012) revealed minimum occurrences of these viruses in few exotic genotypes. Mughal et al. (1988) documented eight viruses in potato crop in Pakistan through ELISA test. Yield reduction occurs in potato when diseased potato tubers are constantly planted as source of seed for many years. In Pakistan, yield reduction in potato crop is documented up to $58-83 \%$ because of viruses (Khalid et al., 2000). PVX affects more than 200 species of plants and many belongs to Solanaceae family (Purcifull and Edwardson, 1991). Cultivation of the resistant genotypes is economical and suitable way to control spreading of diseases caused by viruses. In this regard, a research experiment was conducted to screen out resistant potato genotypes against PVX, PVY and PLRY under agro ecological condition of Pakistan and resistant genotypes could be used for the future breeding programme.

\section{Materials and Methods}

Potato material was originally imported from international potato center Lema Peru and designated as CIP. Tubers were grown in peat moss and process of thermotherapy was done at $35^{\circ} \mathrm{C}$ to eradicate viral infection. Sprouted tubers meristematic part was excised and subjected to tissue culture for 60 days, number of plants were increased by nodal cutting on MS media. At this stage ELIZA was done by using AGDIA KITS separately for PVX, PVY and PLRV and disease free plants were selected. Then there micro and mini tubers were obtained by in vitro and in vivo protocol. These $1^{\text {st }}$ generation tubers were designated as pre basic-I and these tubers were planted to get pre basic-II, which were used in this study.

The experiment was conducted in National Agricultural Research Centre, Islamabad and potato germplasm (Pre-Basic II potato tuber) of 30 exotic genotypes were obtained from Bio Resource Conservation Institute, National Agricultural Research Centre, Islamabad, Pakistan. The area for each genotype was 4 $\mathrm{m} \times 1 \mathrm{~m}$ and design of trial was RCBD with three replications. The experiment was conducted during 2015-16 (November to March). The area of field was $38.5 \mathrm{~m} \times 14 \mathrm{~m}$ and there were 90 plots and area of each plot was $4 \mathrm{~m}^{2}$. Distance between two plots was $0.5 \mathrm{~m}$ while spaced between tubers were $25 \mathrm{~cm}$.

The recommended fertilizer doses i.e. NPK 250,
125 and $120 \mathrm{~kg} \mathrm{ha}^{-1}$ respectively, was used. Crop was regularly monitored during growing season and irrigated when needed.

\section{Observations}

Following observations were recorded during experimental trials.

\section{PVX, PVY or PLRV incidence (\%)}

In order to measure PVX, PVY and PLRV, following formula was used:

$\%$ Incidence of PVX, PVY or PLRV $=\frac{\text { Number of infected plants }}{\text { Number of total plants }} \times 100$

\section{Plant height $(\mathrm{cm})$}

For plant height, 5 plants of each genotype were selected randomly in each replication and their height was measured and then averaged.

\section{Number of shoots per plant}

Number of shoots from 5 plants randomly marked was counted and averaged was taken.

\section{Number of tubers per plant}

To count the number of tuber per plant, 5 plants from each genotype selected randomly in each replication were selected and their tubers were counted and then averaged.

\section{Yield per plant $(g)$}

Yield of potato was determined from each genotype with help of digital balance and converted to $g / h a$.

\section{Shape of the tuber}

For shape of tuber, tuber of 5 plants of each genotype from each replication was visually observed and recorded shape of tuber.

\section{Tuber skin color}

For tuber skin characteristics, tuber of 5 plants of each genotype from each replication was visually observed and noted skin type of tuber.

\section{Tuber flesh color}

For tuber flesh color, tubers of 5 plants of each genotype from each replication were observed carefully and their flesh color was noted.

\section{Statistical analysis}

For yield and yield traits, data were analyzed statistically by applying a computer package program 
Table 1: ELISA results showing potato genotypes resistant and susceptible to PVX, PVY and PLRV.

\section{Genotype}

PVX

@ 2X the average read- Reaction / ing $(405 \mathrm{~nm})$ of negative Remarks control $=\mathbf{0 . 2 3 9}$

CIP1 0.231

CIP $2 \quad 0.236$

CIP $3 \quad 0.220$

CIP $4 \quad 0.229$

CIP $5 \quad 0.222$

CIP $6 \quad 0.224$

CIP $7 \quad 0.230$

CIP $8 \quad 0.212$

CIP $9 \quad 0.228$

CIP $10 \quad 0.244$

CIP $11 \quad 0.226$

CIP $12 \quad 0.225$

CIP $13 \quad 0.228$

CIP $14 \quad 0.216$

CIP $15 \quad 0.217$

CIP $16 \quad 0.225$

CIP $17 \quad 0.224$

CIP $18 \quad 0.209$

CIP $19 \quad 0.219$

CIP $20 \quad 0.225$

CIP $22 \quad 0.209$

CIP $24 \quad 0.206$

CIP $27 \quad 0.217$

CIP $28 \quad 0.237$

CIP $29 \quad 0.219$

CIP $30 \quad 0.226$

CIP $31 \quad 0.232$

CIP $32 \quad 0.214$

CIP $33 \quad 0.231$

CIP $34 \quad 0.216$
PVY

PLRV
@ $2 \mathrm{X}$ the average reading Reaction /

(405 nm) of negative control $=0.307$

$\begin{array}{ll}\text { Resistant } & 0.223 \\ \text { Resistant } & 0.275 \\ \text { Resistant } & 0.369 \\ \text { Resistant } & 0.299 \\ \text { Resistant } & 0.249 \\ \text { Resistant } & 0.240 \\ \text { Resistant } & 0.217 \\ \text { Resistant } & 0.239 \\ \text { Resistant } & 0.373 \\ \text { Resistant } & 0.216 \\ \text { Resistant } & 0.395 \\ \text { Resistant } & 0.298 \\ \text { Resistant } & 0.305 \\ \text { Resistant } & 0.335 \\ \text { Resistant } & 0.290 \\ \text { Resistant } & 0.202 \\ \text { Resistant } & 0.210 \\ \text { Resistant } & 0.224 \\ \text { Resistant } & 0.221 \\ \text { Resistant } & 0.295 \\ \text { Resistant } & 0.221 \\ \text { Resistant } & 0.225 \\ \text { Resistant } & 0.239 \\ \text { Resistant } & 0.299 \\ \text { Resistant } & 0.248 \\ \text { Resistant } & 0.283 \\ \text { Resistant } & 0.296 \\ \text { Resistant } & 0.283 \\ \text { Resistant } & 0.240 \\ \text { Resistant } & 0.224\end{array}$

Remarks

Resistant

Resistant

Susceptible

Resistant

Resistant

Resistant

Resistant

Resistant

Susceptible

Resistant

Susceptible

Resistant

Resistant

Susceptible

Resistant

Resistant

Resistant

Resistant

Resistant

Resistant

Resistant

Resistant

Resistant

Resistant

Resistant

Resistant

Resistant

Resistant

Resistant

Resistant
@ 2X the average read- Reaction / ing $(405 \mathrm{~nm})$ of negative Remarks control $=0.197$

0.147

Resistant

0.144

Resistant

0.151

Resistant

Resistant

Resistant

Resistant

Resistant

Resistant

Resistant

Resistant

Resistant

Resistant

Resistant

Resistant

Resistant

Resistant

Resistant

Resistant

Resistant

Resistant

Resistant

Resistant

Resistant

Resistant

Resistant

Resistant

Resistant

Resistant

Resistant

Resistant
MSTAT-C (Freed and Eisensmith, 1989) and LSD at $5 \%$ probability level was used to compare means.

\section{Results and Discussion}

Results regarding ELISA test for potato genotypes showed that all the exotic genotypes had resistance against potato PVX and PLRV diseases. However; symptoms of potato virus $\mathrm{Y}$ (PVY) was noted in CIP-3, CIP-9, CIP-11 and CIP-14 genotypes, which then confirmed by ELISA test (Table 1). This showed that $13.33 \%$ PVY disease incidence in potato genotypes (Table 2) while no incidence for PVX and PLRV. Agronomic traits (Table 3) showed that potato genotype differed significantly for plant height, CIP-30 recorded maximum plant height (116.33 $\mathrm{cm})$ followed by CIP-27 genotype $(102.67 \mathrm{~cm})$ while CIP-5 genotype had minimum plant height (23.67 $\mathrm{cm}$ ) while other genotypes had medium plant height (Table 3). However, more of number of shoots was depicted for CIP-1 genotype (5.67) followed by CIP-3 (5.33) whereas CIP-27 genotypes showed less number of shoots/plant (2.33) while other genotypes had number of shoots in range of 3.0-4.70 shoots/ plant. Alike, genotypes showed diversity for number of tubers/plant. Genotype CIP-6 exhibited more 
number of tuber/plant (22.0) followed by CIP-18 genotype (17.33) while CIP-20 produced minimum number of tuber/plant (7.33) while rest of genotypes had intermediate number of tubers (8-16 tubers/ plant). Similarly, there was also diversity among potato genotypes for yield/plant. Genotypes CIP-11 and CIP-22 produced the highest tuber yield (462 and 459 g, respectively) while CIP-5 genotype gave minimum tuber yield (75 g) however, other potato genotypes produced tuber yield in range of 142-356 g/plant.

Table 2: Disease incidence (\%).

$\begin{array}{llll}\text { Disease } & \text { PVX } & \text { PVY } & \text { PLRV } \\ \text { Incidence \% } & 0.00 \% & 13.33 \% & 0.00 \%\end{array}$

Table 3: Agronomic traits of potato genotypes.

S. Genotype Plant Number Number of Yield/ No. height $(\mathrm{cm})$ of shoots/ tuber/plant plant

\begin{tabular}{|c|c|c|c|c|c|}
\hline & & & plant & & g) \\
\hline 1. & CIP1 & $30.33 \mathrm{pq}$ & $5.67 \mathrm{a}$ & $8.00 \mathrm{hi}$ & $138 \mathrm{~d}$ \\
\hline . & CIP 2 & $33.33 \mathrm{opq}$ & 3.00 & 00 ghi & $52 \mathrm{~d}$ \\
\hline 3. & CIP 3 & 35.33 nop & $5.33 \mathrm{ab}$ & $17.00 \mathrm{~b}$ & $148 \mathrm{~d}$ \\
\hline 4. & CIP 4 & $46.33 \mathrm{ijklm}$ & $2.33 \mathrm{~h}$ & $7.67 \mathrm{hi}$ & $142 \mathrm{~d}$ \\
\hline 5. & CIP 5 & 23.6 & 4.00 & 9.33 fghi & $75 \mathrm{e}$ \\
\hline 6. & CIP 6 & $32.67 \mathrm{opq}$ & 4.33 & $22.00 \mathrm{a}$ & $230 \mathrm{c}$ \\
\hline 7. & CIP 7 & 39 & 3.3 & ghi & $243 c$ \\
\hline 8. & CIP 8 & 41.671 & $2.33 \mathrm{~h}$ & $12.33 \mathrm{de}$ & $332 \mathrm{~b}$ \\
\hline 9. & CIP 9 & 50. & $2.33 \mathrm{~h}$ & & $281 c$ \\
\hline 10. & CIP 10 & 35 & 3.33 & $67 \mathrm{defg}$ & $462 \mathrm{a}$ \\
\hline 11. & CIP 11 & $55.67 \mathrm{ghi}$ & $2.67 \mathrm{gh}$ & & $253 c$ \\
\hline 12. & CIP 12 & 53.33 ghijk & $2.67 \mathrm{gh}$ & 12. & $261 c$ \\
\hline 13. & CIP 13 & 53.33 ghijk & $3.67 \mathrm{defg}$ & $11.00 \mathrm{efg}$ & $302 \mathrm{~b}$ \\
\hline 4. & CIP 14 & ano & $\mathrm{fg}$ & & $263 c$ \\
\hline 15. & CIP 15 & $45.33 \mathrm{jklmn}$ & $4.67 \mathrm{abcd}$ & 9.00 ghi & $353 \mathrm{~b}$ \\
\hline 16. & CIP 16 & $70.67 \mathrm{de}$ & 3.33 efgh & $11.00 \mathrm{efg}$ & $185 \mathrm{~d}$ \\
\hline 17. & $\mathrm{CIl}$ & 62 & efg & efg & $184 \mathrm{~d}$ \\
\hline 18. & CIP 18 & 70 & $2.67 \mathrm{gh}$ & & $355 \mathrm{~b}$ \\
\hline 19. & CIP 19 & 74 & $2.67 \mathrm{gh}$ & & $354 \mathrm{~b}$ \\
\hline 20. & $\mathrm{CI}$ & 63 & 4.67 & & $343 \mathrm{~b}$ \\
\hline 21. & CIP 22 & $91.67 \mathrm{c}$ & 4.33 & 11.33 defg & $459 a$ \\
\hline 22. & CIP 24 & $9.33 \mathrm{fgh}$ & $3.00 \mathrm{fgh}$ & 9.67 efghi & $d$ \\
\hline 23. & CIP 27 & 10 & 2.3 & gh & $315 \mathrm{~b}$ \\
\hline 24. & CIP 28 & 55.33 ghij & 5.00 & 12. & $356 \mathrm{~b}$ \\
\hline 25 . & CIP 29 & $56.67 \mathrm{gh}$ & $5.00 \mathrm{abc}$ & $7.67 \mathrm{hi}$ & $164 \mathrm{~d}$ \\
\hline 26. & CIP 30 & $116.33 \mathrm{a}$ & $2.67 \mathrm{gh}$ & $16.00 \mathrm{bc}$ & $214 d$ \\
\hline 27. & CIP 31 & $69.33 \mathrm{def}$ & $3.33 \mathrm{efgh}$ & 9.00 ghi & $211 \mathrm{~d}$ \\
\hline 28. & CIP 32 & $55.67 \mathrm{ghi}$ & $2.67 \mathrm{gh}$ & $8.00 \mathrm{hi}$ & $237 \mathrm{~cd}$ \\
\hline 29. & CIP 33 & $60.67 \mathrm{efg}$ & $2.67 \mathrm{gh}$ & 9.00 ghi & $276 \mathrm{c}$ \\
\hline \multirow[t]{2}{*}{30.} & CIP 34 & $44.33 \mathrm{klmn}$ & $2.67 \mathrm{gh}$ & $11.00 \mathrm{efg}$ & $242 \mathrm{~cd}$ \\
\hline & LSD at & 10.050 & 0.5443 & 2.8131 & 43.0 \\
\hline
\end{tabular}

Table 4: Morphological characteristics of potato tubers.
S. Geno-

No. type

1. CIP 1

2. CIP 2

3. CIP 3

4. CIP 4

5. CIP 5

6. CIP 6

7. $\mathrm{CIP} 7$

8. CIP 8

9. CIP 9

10. CIP 10

11. CIP 11

12. CIP 12

13. CIP 13

14. CIP14

15. CIP 15

16. CIP 16

17. CIP 17

18. CIP 18

20. CIP 20

21. CIP22

22. CIP24

23. CIP27

24. CIP28

25. CIP29

26. CIP30

27. CIP31

28. CIP32

29. CIP33

30. CIP34
19. CIP 19
Tuber

shape

Round

Ovate

Round

Round

Elliptic

Round

Elliptic

Round

Round

Elliptic

Elliptic

Elliptic

Ovate

Elliptic

Round

Round

Round

Elliptic

Round

Ovate

Round

Elliptic

Round

Round

Round

Ovate

Round

Elliptic

Round
Round
Tuber skin Tuber flesh Eye depth color color

Yellow White

Medium

Yellow

White

Medium

Yellow

Cream

Shallow

Red

Cream

Shallow

Yellow

Cream

Shallow

Yellow

White

Shallow

White

White

Shallow

Yellow

Cream

Shallow

Yellow

White

Deep

Yellow

Cream

Shallow

Yellow

White

Shallow

Yellow

White

Shallow

Yellow

Cream

Deep

Yellow

Cream

Medium

Yellow

White

Shallow

Yellow

Cream

Shallow

Yellow

Cream

Shallow

Yellow

White

Shallow

Yellow

White

Shallow

Yellow

White

Shallow

Yellow

Cream

Shallow

Yellow

White

Medium

Yellow

White

Medium

Red

Cream

Shallow

Yellow

White

Shallow

Yellow

White

Shallow

Yellow

Cream

Shallow

Yellow

Cream

Shallow

Cream

Shallow

White

Medium
Morphological traits (Table 4) exhibited that potato genotypes produced tubers of various shape, skin color of tuber, flesh color and eye depth of tubers. Majority of genotypes, CIP-1 to CIP-7, CIP-9, CIP-10, CIP16 to CIP-18, CIP-20, CIP-24, CIP-28 to CIP30 , CIP-32 and CIP-34 =produced round shaped tubers while CIP-3, CIP-14, CIP-22 and CIP-31 genotypes had ovate shaped tubers whereas elliptic shaped tubers were produced by CIP-6, CIP-8, CIP11, CIP-12, CIP-13, CIP-15, CIP-19, CIP-27 and CIP-33 genotypes. Similarly, all the genotypes except CIP-4 and CIP-7 produced yellow skin colored tubers. Likewise, genotypes CIP-1, CIP-2, CIP-6, CIP-7, CIP-9, CIP-11, CIP-12, CIP-15, CIP-18, CIP-19, CIP-20, CIP-24, CIP-27, CIP-29, CIP-30 
and CIP-34 had white flesh colored tubers while rest of genotypes produced cream flesh colored tubers. Two genotypes (CIP-9 and CIP-13) had deep eyed potato tubers while CIP-1. CIP-2, CIP-4, CIP-24, CIP-27 and CIP-34 had medium depth eyed tubers whereas rest of genotypes had shallow depth eyed tubers.

Results showed that all the genotypes had resistance against PVX, PLRV but 4 genotypes were infested with PVY (13.33\% disease incidence). Jarjees (2000) used ELISA test for quick identification of PVY and reported important outcomes. The occurrence of PVY in few potato genotypes during study might be assumed because of different reasons such as biotic and abiotic factors and genetic makeup of plant. The screening outcomes disclosed that several environmental factors and more prominently genetic makeup must be concerned in susceptibility and c resistance, which needs to be explored in detail. Results showed that potato genotypes showed significant differences for agronomic and yield traits. It is presumed that the differences in plant height among various genotypes may be due to combined effects of plant genetics, nutrient status of soil and agroenvironmental conditions, under which the plants were grown. It seems that CIP-30 was a genetically taller genotype and might had large root surface area, which absorbed more nutrients and moisture and intercepted more solar radiations during early and entire growth period and resulted in taller plants. Eaton et al. (2017) depicted significant diversity in potato genotypes for plant height and other morphological character of potato genotypes. Our results also corroborated with outcomes of Luthra et al. (2005), Schittenhelm et al. (2006) who also noted variation in plant height. Potato genotypes showed significant difference in tuber shape, skin color and flesh color and these characters depend on genetic makeup of genotype and environmental condition during growing season. Similar outcomes were also depicted by (Subarta and Upadhya, 1997) and Eaton et al. (2017) who revealed that number of tubers, skin color and flesh color vary from cultivar to cultivars and significantly controlled by genetic makeup of plant and environmental conditions. Genotype CIP6 more tubers while minimum tubers/plant was noted for CIP-20 (Table 1). Similarly, CIP-10 and CIP-22 produced maximum tuber yield while CIP-5 genotype yielded less (Table 1 ). The process of tuber formation is influenced by plant genetic makeup
(Subarta and Upadhya, 1997). Kumar et al. (2004) depicted that various genotypes of potato had lot of differences from each other (Kumar et al., 2004). High yielded genotypes may have large size tubers (Patel et al., 2008).

Most of the genotypes produced round shaped and elliptic shaped tubers with yellow and white skin color. Tuber shape and skin color are important external quality characteristics and may vary with in genotypes (van Eck, 2007). Similar results were depicted by Werij (2011). Similarly, the flesh and skin color controlled by several factor and important one is genetic makeup of genotype (van Eck, 2007). Lewis et al. (1998) revealed that flesh color of potato differed significantly because of anthocyanins and carotenoids. If anthocyanin concentration is then tubers have will be red, blue or purple color (Hung et al.,1997; Brown, 2005; Lachmanet al., 2009).

\section{Conclusions and Recommendations}

Genotypes CIP-3, CIP-9, CIP-11 and CIP-14 were found susceptible to PVY virus while all other genotypes had resistant to PVX, PVY and PLRV viruses. Among resistant genotypes, $\mathrm{CIP}-10$ and CIP22 had maximum yield and could be recommended for commercial cultivation

\section{Acknowledgements}

Authors acknowledge the support from Potato Program and Bio-conservation Institute of National Agriculture Research Centre, Islamabad, Pakistan. Author are also thankful for the technical support of virology lab of NARC Islamabad.

\section{Novelty Statement}

Use of disease free seed is one of the durable and economical method for increasing potato production in Pakistan and this study highlights the determination of four exotic genotypes which had no resistance against PVY in Pakistan.

\section{Author's Contribution}

Arifa Khan, Principal author, conceived the idea, conducted the research and prepared the $1^{\text {st }}$ draft. Naveeda Riaz, Planned and supervised the research and experiments. Shazia Erum, Co-supervised the 
research. Tariq Rafique PSO in BCI, Shahid Riaz provided samples of potato. DR Zafar Iqbal guided in writing up. Danish Anwar Help in data recording.

\section{Conflict of interest}

The authors have declared no conflict of interest.

\section{References}

Abbas, M.F., S. Hammed, A. Rauf, Q. Nosheen, A. Ghani, A. Qadir and S. Zakia. 2012. Incidence of six viruses in potato growing areas of Pakistan, Pak. J. Phytopathol., 24: 44-47.

Brown, C., 2005. Antioxidants in potato. Am.J.Potato Res., 82:163-172.https://doi.org/10.1007/ BF02853654

Eaton, T.E., A. Kalam, K. Humayun and A.B. Siddiq. 2017. Evaluation of six modern varieties of potatoes for yield, plant growth parameters and resistance to insects and diseases. Agric. Sci., 8: 1315-1326. https://doi.org/10.4236/ as.2017.811095

Freed, R.D. and S. Eisensmith. 1989. MSTAT-C, A software package for the design management, and analysis of agronomic experiments. Michigan State University, East.

Hameed, A., Z. Iqbal, S. Asad and S. Manoor. 2014. Detection of multiple potato viruses in field suggests synergistic interaction among potato viruses in Pakistan. Plant Pathol. J., 30 (4): 407-415. https://doi.org/10.5423/PPJ. OA.05.2014.0039

Hung, C.Y., J.R. Murray, S.M. Ohmann and C.B.S. Tong. 1997. Anthocyanin accumulation during potato tuber development. J. Am. Soc. Hortic. Sci., 122: 20-23. https://doi.org/10.21273/ JASHS.122.1.20

Jarjees, M., 2000. Application of enzyme linked immunosorbent assay (ELISA) for rapid detection of potato virus $\mathrm{Y}$ in Iraq. Arab. J. Plant Prot., 18(1): 46-50.

Khalid, S., S. Iftikhar, A. Munir and I. Ahmad. 2000. Potato diseases in Pakistan, PARC. Islamabad, pp. 165 .

Kumar, D., B. Singh and P. Kumar. 2004. An overview of the factors affecting sugar content of potatoes. Ann. App. Biol., 145: 247-256. https:// doi.org/10.1111/j.1744-7348.2004.tb00380.x

Lachman, J., K. Hamouz, M. Sulc, M. Orsák, V. Pivec A. Hejtmánková and P. Dvorák. 2009. Cultivar differences of total anthocyanins and anthocyanidins in red and purple-fleshed potatoes and their relation to antioxidant activity. Food Chem., 114: 836-843. https://doi. org/10.1016/j.foodchem.2008.10.029

Lewis, C.E., J.R.L. Walker, J.E. Lancaster and K.H. Sutton. 1998. Determination of anthocyanins, flavonoids and phenolic acids in potatoes. I: coloured cultivars of Solanum tuberosum L. J Sci. Food Agric. 77:45-57.

Lutaladio, N., O. Ortiz, A. Haverkort, and D. Caldiz., 2009. Sustainable potato production; guidelines for developing countries. Rome: FAO.

Luthra, S.K.J., S.K. Gopal and S.B.P. Pandy. 2005. Genetic parameters and characters associated in tuberosum potatoes. Potato J., 32: 234-239.

Mughal. S.M, S. Khalid, T.S. Gillani, and A. Devaux. 1988. Detection of potato viruses in Pakistan, In Proceeding $2^{\text {nd }}$ Triennial Conference Kunming China, pp. 189-190.

Patel, C.K., P.T. Patel and S.M. Chaudhari. 2008. Effect of physiological age and seed size on seed production of potato in North Gujarat, India. Potato J., 36: 18-23.

Purcifull, D.E. and J.R. Edwardson. 1991. Potato potex virus. Comparative diagnosis, (Ed.): E. Kurstak. Elsevier/North Holland. Bigmend, Pr. Amsterdam. pp. 627-693.

Schittenhelm, S., H. Sourell and F.J. Löpmeier. 2006. Drought resistance of potato cultivars with contrasting canopy architecture. Eur. J. Agron., 24: 193-202. https://doi.org/10.1016/j. eja.2005.05.004

Subarta, M. and M.O. Upadhya. 1997. Potato production in western Bengal. Environ. Ecol., 15: 646-649.

Van Eck, H.J., 2007. Genetics of morphological and tuber traits. In: D. Vreugdenhil, et al. (Eds.). Potato Boil. Biotechnol. Elsevier Sci. B.V. Amsterdam. pp. 91-115. https://doi.org/10.1016/ B978-044451018-1/50048-8

Werij, J., 2011. Genetic analyisis of potato tuber quality traits, Laboratory of plant breeding, Wageningen University, Wageningen. pp. 125. 